\title{
27. China and the global trading system: Then and now
}

\section{Peter Drysdale and Samuel Hardwick}

\section{The achievement}

Openness to international trade and investment has been integral to Chinese economic transformation over the past four decades. Within that relatively short time, China has profoundly changed the way it engages with the rest of the world. The development of domestic markets-a key element of Chinese reform-has been significantly enhanced by integration into international markets via trade, investment flows, technology transfers, people-to-people exchanges and the spread of knowledge.

China's reforms coincided with an era of increasing globalisation, which was characterised by a more open global trading environment resulting from significant reduction in tariffs and other forms of trade protection. In the postwar period, these reforms were driven by various rounds of multilateral trade negotiations under the auspices of the General Agreement on Tariffs and Trade (GATT) and, later, the World Trade Organization (WTO). After the late 1980s, unilateral liberalisation in the Western Pacific region gathered pace under regional cooperation arrangements such as the Asia-Pacific Economic Cooperation (APEC) forum.

The new era was marked by two key factors: rapid adjustment in the structure of world trade in response to more open cross-border flows of goods, capital, people and technology; and rapid reductions in transaction costs because of substantial improvements in transport, communication and information technologies. International markets presented China with opportunities greater than those available during Japan's and South Korea's periods of extraordinary growth (Brandt and Rawski 2008: 13). China's seizing of these opportunities has enhanced global interdependence to a degree the world has never seen before.

China's integration into the global economy brought one-fifth of the world's population into the international economic system, increasing market potential and integration to an unprecedented level. The increased scale and depth of international specialisation propelled by enlarged global markets offered new opportunities to

1 We are most grateful to Nishanth Pathy for his excellent and expeditious editorial and substantial input into the final form of this chapter, and to Shiro Armstrong for his wise suggestions in the crafting of its argument. Any remaining errors are, of course, our responsibility alone. 
boost world production, trade and consumption, with the potential for increasing the welfare of all countries involved (Golley and Song 2011). It promised an era of unsurpassed global economic growth and prosperity-a 'golden age' of world economic growth.

The promise of the golden age is now under a shadow. The era of globalisation is challenged, in part because of the shifts in the global economy and global power that China's trade and economic success delivered to the world; in part, because of deep structural problems and their mismanagement in other countries. The dimensions of the challenge, and what course might be open to deal with it, we turn to at the end of the chapter.

\section{Multilateralism and China's trade story in perspective}

A global framework promoting open trade and investment enabled China's integration into the world economy. A central element was the rules-based GATT and then WTO trading system. While much of China's early economic engagement with the world was concentrated in the Asia-Pacific region, it was China's accession to the WTO, the commitments it made in the process leading up to that and its acceptance of the global rules that underpinned its international economic integration.

Although China had taken important steps towards liberalisation and regional engagement in the reform of its economy and trading system prior to 2001notably through the establishment and spread of special economic zones (SEZs) and successive rounds of trade liberalisation-WTO accession was a watershed moment in China's trade and economic reform. Joining the WTO drove a suite of domestic reforms, lifted investor confidence in China at home and abroad and precipitated rapid growth in China's contribution to world trade. Now, 17 years on, amid pressing new developments that are shaking global economic governance, China and its partners have a major joint stake in securing those interests in a healthy, WTO-led global trading system.

There were many twists and turns along the 15-year road towards WTO accession. APEC, a regional initiative with global objectives, offered a critical pathway. The 1995 APEC summit in Osaka provided the platform for China to announce a massive unilateral trade liberalisation-the largest ever undertaken by a single country in the postwar period-as down payment on the way to WTO accession.

China's economic reform became increasingly linked to trade liberalisation. In the mid-1980s, China embarked on opening up procurements of strategic raw materials such as iron ore from international markets through large-scale purchases 
from Australia. These were necessary as inputs into developing modern industrial capacity. This initiative has profoundly changed China's participation in the international economy. China also saw common cause with the interests of developing economies in dismantling export controls over trade in textiles and other labour-intensive exports. Through Asian economic cooperation, particularly through APEC, China embraced a globalist, multilateral approach to international integration. Like other regional players, China was favoured by an open approach to integration under the multilateral trading system in fostering trade expansion (EABER and CCIEE 2016: 40).

The protocols of Chinese accession to the WTO were more demanding than those placed on other developing economies and even those of established developed country members (namely in respect of limitations on the application of export controls) (Branstetter and Lardy 2008: 655). China's commitment to the protocols of accession to the WTO entailed large-scale national economic reform. Markets in manufacturing and commodities across the country became increasingly open and competitive. This process saw deeper integration of the national economy and accelerated the integration of the Chinese economy into international markets. The effect of reforms and integration was not simply a more efficient allocation of resources through the closer alignment of domestic with international prices - that had largely been achieved in the half-decade or so before accession. The substantive impact of the regime change was WTO members' and China's new confidence in undertaking trade with one another-trade that rose dramatically in the years immediately after accession in 2001 (Armstrong 2012).

The global system, underpinned by the GATT/WTO and multilateral financial institutions, was never static. It has evolved, for example, in managing international trade rules, through the GATT to the WTO with its stronger dispute settlement mechanisms. New economic and political risks and challenges required the adaptation and evolution of these institutions and their supplementation with others. The global financial crisis (GFC) saw the emergence of the G20 as a forum for national leaders. China's rise as a source of international capital later saw its commitment to the Asian Infrastructure Investment Bank (AIIB) and the Belt and Road Initiative (BRI). But there remain many areas of international commerce, such as foreign direct investment (FDI), not covered by the comprehensive multilateral regime, such as that which governs trade. Rapid shifts in the structure of the global economy and the digital revolution are now creating enormous pressure to strengthen and adapt international trade institutions to deal with these new pressures.

An increasingly important dimension of world trade, for which the rules are still being written, is the free and secure movement of digital data across borders. The growth of the digital economy means that domestic data regulations, including data localisation and internet filtering, have the potential to present significant obstacles to free trade (Meltzer 2017). Yet the treatment of data regulation in 
the global trade architecture remains underdeveloped. A stronger framework for addressing these issues (and others in the cybersecurity domain) will be necessary for the next phase in writing the rules of the global economy. As a major economy, China will have to play a substantive part in this.

Another question is the use of trade-restrictive measures in political disputes. There are legitimate applications of trade sanctions under international law, such as the trade sanctions imposed on North Korea (which, in any case, is not a signatory to the WTO) under UN resolutions. ${ }^{2}$ But there are also instances in which China and other countries have deployed commercial restrictions in political retaliation against trading partners, such as in the case of China's retaliation to South Korea's Terminal High Altitude Area Defense (THAAD) announcement in March 2017. These cases highlight areas where international rules are inadequate or underdeveloped, or where norms and expectations are seen as malleable. How to manage these political risks around hard-letter rules is now an active object of interest in the working of the global economic system.

Healthy, rules-based and inclusive global institutions have been and continue to be central to the prosperity of China and its economic partners. The region's long-term economic and political stability and security will depend in significant part on how resilient global institutions are to the pressures put on them by shocks and structural changes in the global economy, and how those institutions adapt to these changesin particular, to the rise of China and other emerging economies.

\section{Liberalisation and reform}

In 1980, two years into China's reform and opening, the Chinese economy accounted for 2 per cent of global gross domestic product (GDP). Today, it is the world's largest economy in purchasing power parity (PPP) terms and the second largest - at 15 per cent of global GDP - as measured at current exchange rates in US dollars. Much of the near double-digit growth between 1980 and $2016^{3}$ stemmed from the more efficient allocation of resources that came with the transition from a planned to a mixed market economy. A major driver, however, particularly after 2001, was export growth (Yao 2013: 45).

Rapid industrialisation and waves of rural-urban migration gave China its comparative advantage in labour-intensive manufacturing industries (Yao 2013: 51). The move to freer trade, facilitated by participation in regional and global arrangements, unlocked this potential and enabled China to become the world's leading exporter of manufactured goods-a position it has retained each year since

2 The latest of which is Resolution 2375, restricting crude oil imports.

3 Authors' calculations based on data from the World Bank (2018). 
2008 (WTO Secretariat 2018). China's share of world manufacturing exports expanded most rapidly in the period following WTO accession, from 5 per cent in 2001 to 17 per cent in 2016 (Figure 27.1).

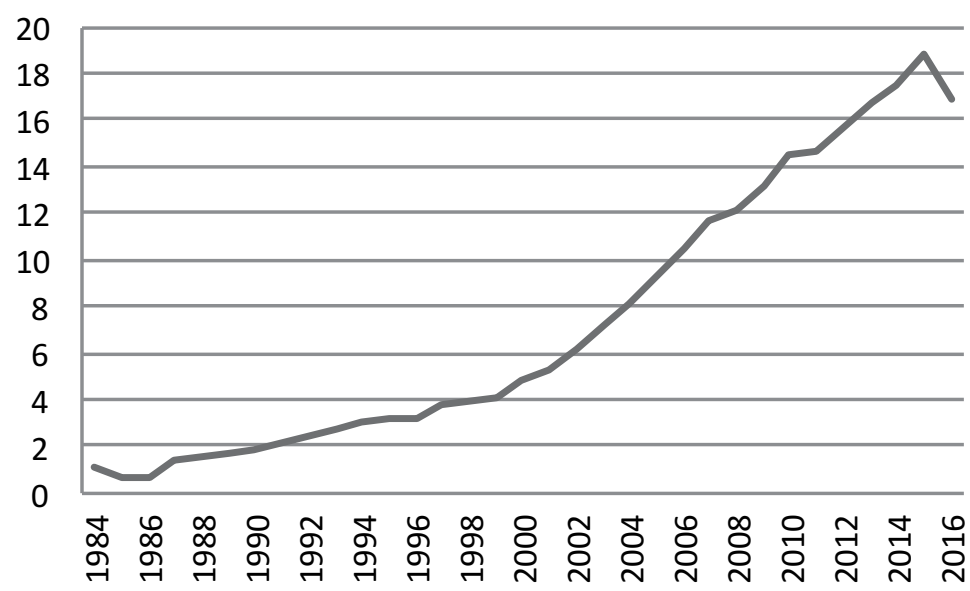

Figure 27.1 China's share of world manufacturing exports, 1984-2016 (per cent) Source: Authors' calculations based on data from the World Bank (2018).

Massive migration from rural to urban China supplied the labour force needed to fuel industrialisation. Without the internationalisation of China's economy, there would have been no way for China's industrial sector to absorb the large number of rural migrant workers. A key element of China's integration into the global economy therefore has been the absorption of a large proportion of rural migrant workers into its booming export sector. This allowed a process of unprecedented urbanisation to take place, increasing the urban population by about 300 million over the past 30 years. This urbanisation contributed to gains in Chinese productivity, rapid economic growth and increasing shares of world production and trade (Song 2013: 25).

This pattern of development enabled China to capitalise on its underlying comparative advantage, although what constitutes China's comparative advantage has itself changed dynamically over time. At the beginning of the reform period, exports were predominantly agricultural products and primary goods such as coal and oil. During the first two decades of reform, the share of labour-intensive products such as textiles rose. In the first decade of the twenty-first century, exports of capitalintensive products such as steel, machinery, electronics and automobiles were on the rise. In the future, China is more likely to produce and export technology-intensive products such as equipment, software and green technology (Song 2013: 25-6). 
China has been one of the biggest beneficiaries of globalisation over the past 30 years, gaining enormously from engaging in international production, trade, capital flow, technological transfer and people-to-people interactions. This was especially true after China entered the WTO in 2001. China's average tariff rate was reduced further, from 14.1 per cent in 2001 to 3.7 per cent in 2010. During this 10-year period, China's total exports and imports increased by 5.9 and 5.7 times, respectively, and its total GDP more than doubled. In 2016, China's total imports amounted to US\$1.6 trillion, accounting for 11 per cent of world imports. ${ }^{4}$

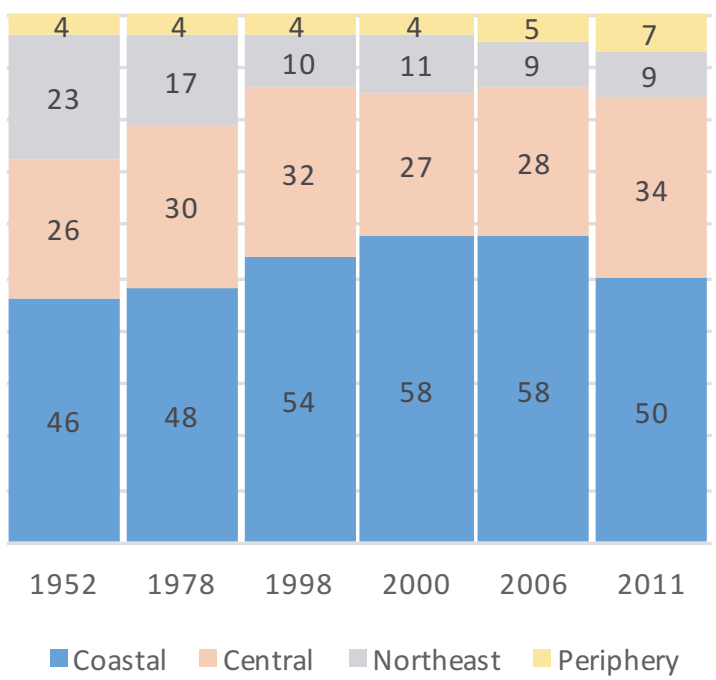

Figure 27.2 Regional distribution of industrial value added, 1952-2011 (per cent) Notes: Regional categorisations are based on Lemoine et al. (2015). 'Coastal' includes Fujian, Guangdong, Hainan, Hebei, Jiangsu, Shandong, Zhejiang, Beijing, Shanghai and Tianjin. 'Central' refers to Anhui, Chongqing, Gansu, Guizhou, Henan, Hubei, Hunan, Jiangxi, Qinghai, Shaanxi, Shanxi, Sichuan, Yunnan and Chongqing. 'North-east' includes Liaoning, Jilin and Heilongjiang. 'Periphery' includes Guangxi, Inner Mongolia, Ningxia, Tibet and Xinjiang. Lemoine et al. (2015: 60) find that China has entered a 'new phase in its growth trajectory' since the mid-2000s, marked by the rebalancing of economic growth and industrial output away from the coast.

Sources: Compiled from Lemoine et al. (2015: 45) and data from the National Bureau of Statistics of China (NBS various years).

For China, economic openness also functioned as a catalyst to domestic institutional and policy reform. Embarking on the long road towards accession to the GATT, and later the WTO, meant eventual and fundamental change to China's basic institutional and policy settings. As Chinese policymakers struggled with building the domestic market economy in the first two decades of the reform period, the years after WTO accession served to entrench them nationally (Gewirtz 2017: 265-6). Adhering to WTO principles not only made China's trading regime more transparent, reliable

4 Export and import data are from World Integrated Trade Solution (WITS 2018). Weighted average tariff and GDP data are from the World Bank (2018). 
and efficient. More importantly, in complying with WTO requirements, Chinese institutions-economic, legal, social and political-have also become more aligned with international practice. These institutional changes contributed to the Chinese economy's remarkable performance post-WTO accession through their impact across the whole economy. This is seen most readily in the growing share of manufacturing and national output outside the SEZs and preferenced coastal zones after 2001 (see Figure 27.2).

China joining the WTO was a strategic and economic milestone, but it was not a turning point in the direction of reform and trade liberalisation. China had already undertaken gradual unilateral steps to liberalise its international trade in the 1980s. This push ramped up in the lead-up to accession (Branstetter and Lardy 2008: 634-5).

China first requested to rejoin the GATT in 1986 (Liang 2002: 685). ${ }^{5}$ The path to joining the WTO was marked by multiple rounds of concessions and more than one dead end. Negotiations collapsed after the Tiananmen Square incident in 1989 and hit another major stalemate in 1994.6 After making substantial additional commitments - including on tariffs, intellectual property rights and service sector access - China signed bilateral WTO accession agreements with the United States in November 1999, and with the European Union in 2000.

After opening up to international trade, China's access to the US market was initially circumscribed under the Jackson-Vanik provisions of the Trade Act of 1974 under which the US president had power to deny 'permanent normal trade relations' to states that impeded the right or opportunity of its citizens to emigrate and had not signed a bilateral commercial agreement with the United States. The JacksonVanik provisions required the issue of a yearly presidential waiver to allow China's access to the US market until its signing of the bilateral treaty of accession to the WTO (Pregelj 2005: 10). Removal of the huge uncertainties around the JacksonVanik waiver was a significant boost to confidence in trade with the United States, which in the first two decades of China's opening up had been underrepresented in Chinese markets.

5 Australia not only encouraged China's entry into large-scale international resource procurements at this time, it also became a principal source of technical assistance and advice on the long path to WTO accession (EABER and CCIEE 2016: 40, 185-6).

6 China aimed to join the GATT by the end of 1994, as a founding member of the WTO. After China made substantial concessions throughout that year, the United States requested that China join GATT as a developed country and presented a new set of reform guidelines. These guidelines proved politically untenable for China, and negotiations entered a stalemate in late 1994. Informal talks between China and GATT parties restarted in mid-1995, with more talks scheduled for October. The October talks were postponed at the request of the United States, but rescheduled following then president Jiang Zemin's liberalisation announcement at the November APEC summit in Osaka. See Liang (2002: 698, 703, 707). 


\section{Regional path to WTO accession and global integration}

From 1991, APEC was the primary international forum facilitating China's liberalisation. With Beijing formally espousing open regionalism in 1995, APEC provided China with a platform to communicate its reform goals, demonstrate credibility ahead of WTO accession and make large-scale voluntary commitments to unilateral liberalisation in the context of APEC's individual action plans.

China's unilateral trade reforms in the 1990s, like its participation in APEC, cannot be viewed independently of its broader strategic goal of WTO accession. At that time, China's approach to its existing international agreements was an indication that its entry to the WTO would represent an assurance of credibility and commitment to the steps it had already taken (Drysdale 2000: 19). In April 1999, then premier Zhu Rongji made clear the role of WTO accession in his broader national reform strategy, declaring at a press conference in the United States:

If China wants to join the WTO ... then China must play by the rules of the game. China cannot do that without making concessions ... such concessions might bring about a very huge impact on China's national impact on some state-owned enterprises, and also on China's market.

But ... we will be able to stand such impact. And the competition arising from such impact will also promote a more rapid and more healthy development of China's national economy. (Office of the Press Secretary 1999)

When Zhu made these comments, China was nearing the end of a decade of transformative reform and liberalisation. It had abolished export subsidies and then lowered tariffs on 43 commodities in 1991. Further tariff cuts occurred in 1992, 1993, 1996 and 1997, with China's weighted average tariff rate falling from 32 per cent to less than 16 per cent over these years (World Bank 2018).

There were also breakthroughs in the liberalisation of services, which was then China's most protected sector. In 1992, the first foreign insurance firm opened for business, in Shanghai and Guangzhou, and, in 1995, Morgan Stanley and the China Construction Bank formed China's first joint-venture investment bank (Zhang 2000: 8). The number of domestic firms given international trading rights expanded from 800 in 1985 to 12,000 a decade later, and to 35,000 by 2001 (Branstetter and Lardy 2008: 635).

The 1990s saw major reform of import quotas and licensing, alongside broader shifts in the nature of government intervention in firms' activities. 'Mandatory plans' setting export quotas and rules around the use of foreign exchange were replaced with 'guidance plans', in which intervention was conducted primarily through taxes, credit and exchange rate policy (Zhang 2000: 7). In the late 1980s, at their peak, quotas and licences covered nearly half of all Chinese imports; that had dropped to around 18 per cent by the end of 1992 (Branstetter and Lardy 2008: 635). 


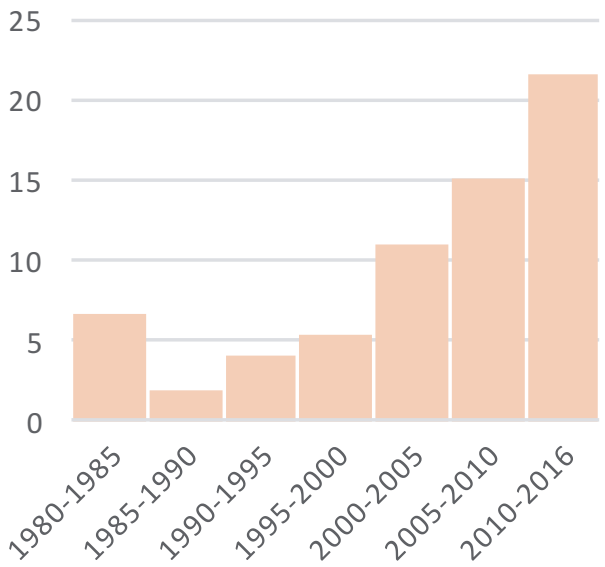

Figure 27.3 China's share of world trade growth, 1980-2016 (per cent) Note: Trade here equals imports plus exports.

Source: Authors' calculations based on data from WTO Secretariat (2018).

APEC's role was important in making this liberalisation possible, and in shaping China's path to the WTO. Its flexibility and emphasis on concerted unilateral action made it the ideal vehicle for China-a developing country then in the relatively early stages of transition from a planned to a market economy-to articulate its reform ambitions on the regional stage, where its international interests were largely concentrated. APEC provided a platform for China to demonstrate its willingness and political capacity to undergo economic reform and pursue greater integration with the global economy. In 1995, at the Osaka APEC meeting, then Chinese president Jiang Zemin declared a 30 per cent tariff cut on 4,000 import itemsan effective reduction of China's average tariff rate from 36 per cent to 23 per cent in one fell swoop (Zhang 2000: 11-12).

APEC's system of individual action plans (IAPs) and collective action plans (CAPs) - annual reports that documented countries' free trade and investment policies and goals_ - provided transparent, externally reviewed guidelines for China's trade reforms in the years after Osaka. China's 1996 IAP, for example, set goals of cutting average tariff rates to 15 per cent by 2000, 10 per cent by 2010 (both of which were achieved) and 5 per cent by 2020 (which has been achieved already) (Zhang 2000: 11). ${ }^{7}$

An essential part of China's 1990s APEC strategy was gathering regional support for its WTO accession. Australia from the very beginning encouraged China's application to join the WTO and provided ongoing technical assistance along the way. Through demonstrating its commitment to its East Asian and Pacific

7 Weighted average tariff data from the World Bank (2018). 
neighbours on a range of issues, China's participation in APEC consolidated its support in the region. And, as with joining the WTO, China's APEC commitments provided impetus for domestic reform through drawing on external pressure (Yang and Huang 2000: 91).

China and other Asian economies became integral parts of supply chains that drove economic integration and growth in East Asia and globally. Through these supply chains, emerging economies in East Asia joined the globalisation process and embraced the rules of an open trade and investment regime. Fears in South-East Asia of competition from China were proven to be unfounded given the opportunities that opened up from joining expanded production networks centred on China. APEC played an important role in leading this process through concerted unilateral liberalisation, including China's massive liberalisation before its accession to the WTO (Garnaut 2012: 22). APEC also laid the groundwork for the information technology agreement that liberalised trade in electronic products and was critical to building Asian supply chains. These were the foundations for comprehensive Asian and trans-Pacific economic integration and multilateral cooperation.

\section{Impact on trade and investment}

For China, WTO membership ushered in a period of unprecedented trade growth (Figure 27.3). The rise of global production networks meant important opportunities for China's export and processing trade growth and major rewards for China's greater integration with the global economy-something then premier Zhu Rongji and China's head negotiator, Long Yongtu, understood well throughout the accession process. In 2000, Long wrote:

planned economies have never been part of economic globalisation. China's economy must become a market economy in order to become part of the global economic system, as well as the economic globalisation process. (Quoted in Branstetter and Lardy 2008: 650)

There has arguably been no country for which WTO accession has involved deeper economic, institutional, legal and political change and reform than China (Halverson 2004: 322). China made more substantial reform commitments in joining the organisation than had previously been required of any new member. Although classified as a developing country (despite deep objections from the United States), China agreed to a range of concessions from which developing countries were typically exempt (Garnaut and Huang 2000: 27).

As part of its accession arrangement, China committed to lower its average industrial tariff rate to 8.9 per cent, to remove all licence requirements and import quotas on manufactured goods before 2005 and (with a small number of exceptions) to abolish the 'designated trading' system (whereby the central government permitted 
selected domestic companies to trade certain commodities internationally). China agreed to cut the average statutory tariff rate for agricultural goods from 21 per cent to 15 per cent, meeting developed country protocols (Branstetter and Lardy 2008: 650-3). The accession agreement also involved substantial opening in servicesparticularly in distribution, telecommunications, education, banking and financial services. By 2004, it had phased out all geographic and ownership restrictions on retail and wholesale activities (Branstetter and Lardy 2008: 657).

The 2017 Office of the US Trade Representative (USTR) report on WTO compliance acknowledged China's compliance with its WTO commitments on trading rights, its timely abolition of quotas and the designated trading system and its progress on tariff cuts (Office of the USTR 2018: 33-8).

The reforms that accompanied WTO accession significantly improved China's FDI regime in terms of national treatment and transparency. China's FDI policies since 2001 have placed greater emphasis on consistency and conformity with international rules (Chen 2011: 85). WTO membership meant the introduction of an independent judicial review and, for multinationals in China, a dispute resolution mechanism with the opportunity for appeal (Armstrong 2009: 116). Membership also put external pressure on competition and industrial policy reform, as well as intellectual property rights and enforcement (Chen 2011: 85), although this remains an area of real dispute with the United States, Europe and Japan. In the five years following accession, Chinese inbound FDI flows grew at an annual average of 22 per cent (compared with 4 per cent in the five years prior) ${ }^{8}$ and China became significantly more open to foreign investment than most countries at a similar level of development and many of its Asian neighbours, including those that were much more developed.

The impact of WTO membership on investor confidence and Chinese policy credibility - though harder to measure-is central to understanding the calculus of participation in the global rules-based system. WTO accession mitigated information asymmetry and unpredictability, which signalled (in the case of Japanese firms) China's arrival as a 'real market'-despite historically being seen as a risky investment environment (Armstrong 2009: 118).

Reform-minded Chinese policymakers used WTO membership to overcome domestic political resistance to reform and reform fatigue. International engagement became an engine of domestic development and reform (Armstrong 2009: 113).

The belief that the WTO is a 'public good' has taken hold in China, and membership in the WTO is a driving force for market reforms. WTO entry transformed how the global multilateral trading system is viewed, not only by sceptics in the government but, more importantly, in the public mindset. (Wang 2011)

8 Authors' calculations based on data from the World Bank (2018). 


\section{Preferential trade and the new regionalism}

China's powerful trade and economic growth accelerated the rise of East Asian economies as a major centre of global economic integration. But towards the end of the 1990s, on the cusp of China's accession to the WTO, the Asian Financial Crisis saw an undermining of confidence in global solutions and in Washington's commitment to them. These were the circumstances that spawned the establishment of the Association of Southeast Asian Nations Plus Three (ASEAN+3) arrangements and the emergence of a new regionalism in East Asia. This was not only a consequence of Asia's complex response to Washington's handling of the Asian Financial Crisis; there was also a more general loss of faith in global arrangements such as the International Monetary Fund (IMF) and in the capacity of APEC to deal with the problems of the time. There had been intensification of preferential trading initiatives elsewhere in the world-with the negotiation of the North American Free Trade Agreement (NAFTA) and the extension of Europe's preferential arrangements - that cut across the principles of open regionalism on which APEC had been built. All these developments seemed to justify heading off in a new direction with ASEAN+3 and the negotiation of preferential trading arrangements in East Asia (Drysdale and Terada 2007; Drysdale and Armstrong 2015: 180-1). ${ }^{9}$

What emerged in East Asia and across the Pacific was the proliferation of a set of preferential bilateral trade arrangements-Asian countries have signed more than 110 since 2001 - ordered around the power and leverage of the larger economies. Although ASEAN was a target for several of these arrangements, the different character of the ASEAN-plus bilateral free-trade areas still reflected the interests of the larger partners. Japan was at the centre of this shift in international economic diplomacy, but China's agreement with ASEAN was among one of the first major successes in East Asian bilateral trade diplomacy (Drysdale and Armstrong 2015: 182-3).

Bilateral trade agreements had little impact on trade gains; the liberalisation benefits were extremely limited and their rules-of-origin provisions flew in the face of trade that was increasingly intermediated through production networks across many countries in the region and beyond. Bilateral trade agreements were pursued as diplomatic trophies more than for the contribution they might make to economic welfare through trade reform (Drysdale and Armstrong 2015: 184). Importantly, Asia's trade is multilaterally oriented across the region and globally, so the structure of Asian trading interests recommended much more broadly based regional or multilateral trading arrangements-hence the attraction to 'megaregional' agreements that were outward-looking and sought to embrace a global liberalisation

9 The China-ASEAN framework agreement was signed in November 2002 and an FTA came into force in 2010. A China-New Zealand FTA was signed in 2008, and a China-Australia FTA was initiated in 2005 and signed in 2014 . 
agenda. Reform and opening had been undertaken in a global context and had been underpinned by the global trading system. Asian interests are still best managed in that context (Armstrong and Pangestu 2018: 31).

The launch of negotiations on the Trans-Pacific Partnership (TPP) (in APEC's backyard, led by the United States) and, later, on the Regional Comprehensive Economic Partnership (RCEP) (under the umbrella of ASEAN) dominated thinking about regional integration over the past half-decade. RCEP, unlike the TPP, involved all of Asia's major economies. Both agreements were designed in part to leverage value out of the plethora of bilateral free trade agreements (FTAs) negotiated over the preceding 15 years. The TPP was explicitly a key element in the Obama administration's 'pivot to Asia'. Having not been invited to participate in the TPP, China remained open to TPP membership and framed its participation in RCEP in the broader context of the idea of the Free Trade Area of Asia and the Pacific (FTAAP) through APEC (APEC 2014). Although the many bilateral FTAs already signed brought no significant trade or domestic reform in the region, the difficulties in concluding the Doha Round of negotiations produced a hiatus in multilateral trade reform and shifted emphasis to these megaregional trade initiatives.

Today, with US President Donald Trump's withdrawal from the TPP and his assault on multilateral trade arrangements, there is deep uncertainty about strategies to protect Asia's interests in the global trade regime. China's response to these new circumstances will be crucial. China's integration into the international economy was engineered under the umbrella of multilateral liberalisation, as earlier was Japan's and that of the rest of Asia. China remains, as President Xi Jinping made clear at the World Economic Forum in Davos in 2017 and the Boao Forum for Asia in April 2018, a major stakeholder in the established international trading system (Xi 2017; Bloomberg News 2018).

The breakdown of Doha Round negotiations gave impetus to region-wide arrangements such as the TPP and RCEP as instruments of regional reform and liberalisation. Since the election of President Trump, they have also become important weapons in the armoury for defending against the assault on the international trading system.

The United States withdrew from the TPP on President Trump's third day in office. It remains highly unlikely there will be a serious US effort to rejoin the TPP in the medium term. Despite its smaller size and geopolitical importance, the renamed Comprehensive and Progressive Agreement for Trans-Pacific Partnership (CPTPP), signed in March 2018 and still to be ratified by most signatories, declared the willingness of Asian and Pacific leaders to hold the line against rising US protectionism. It may also yet give momentum to the completion of RCEP negotiations, which involve seven of the 11 CPTPP members, plus China and India (Armstrong 2018). 
The CPTPP freezes certain US-led intellectual property provisions in the TPP, including patent term extension obligations, which makes the agreement more attractive for regional developing countries to join. China's entry, however, is a distant prospect, as each CPTPP signatory has veto power over new entrants, even if they meet requirements.

RCEP—ASEAN's response to the TPP—is the most significant proposal for trade liberalisation on the table today in Asia or, for that matter, anywhere in the world. It matters because of its size and scope and because it involves the negotiation not only of binding liberalisation, but also of economic cooperation goals. Since China, India, Indonesia and other developing countries in Asia will have trouble joining the TPP in the foreseeable future, an ambitious and high-quality RCEP can help promote integration across the Asia-Pacific region. If RCEP governments are to maximise the value of economic integration and freer trade, they will need to go beyond negotiating a single-undertaking trade deal along TPP lines (Drysdale 2016). Leveraging ASEAN centrality, RCEP will be crucial for deepening this economic interdependence, moving the region closer to a single market and production base and thus underpinning future political and security cooperation in the region (Drysdale 2017: 78). RCEP's strengths—its size and its economic and political diversity - are also its major challenges. Yet in the context of a declining US presence in Asia, greater economic interdependence and cooperation between smaller regional players will be more important for outcomes in the Asia-Pacific, both economically and politically.

The 16-country RCEP offers an opportunity:

to salve the sometimes fractious political relations among the Asian powers. Just as the TPP provided cover for Japan to do a deal with the United States, RCEP provides cover for improved Chinese-Japanese and Chinese-Indian economic relations where political sensitivities might make negotiating bilateral deals too difficult. (Armstrong 2017)

Habituating China and other rising economies in a rules-based system in this way would further regional economic integration and also be an important Asian contribution to keeping the global trading system open. This would reinforce geopolitical stability in the Western Pacific while making a bold commitment to global openness (Armstrong 2017).

\section{Globalisation and connectivity}

Connectivity is increasingly seen as a major factor in realising the potential from economic integration. An important dimension of improving connectivity and development outcomes is infrastructure investment. 
The BRI, which encompasses the multilateral AIIB, is a major new Chinese strategy for achieving sustainable development through strengthening connectivity with partner countries and realising mutually beneficial economic relations. It is an overarching strategy of enormous scale and ambition for deepening China's integration into the international economy. Its aims are many-including securing increased openness through improved connectivity and achieving inclusiveness based on mutual interest and benefit-but they are, importantly, directed to expanding global frontiers of growth through sustainable development. It offers a framework for deepening international economic cooperation through a platform of open regionalism that promotes economic integration through improving five types of links: policy, infrastructure, trade and investment, financial exchanges and people-to-people exchanges (EAF 2017).

The BRI's core objectives relate to building infrastructural capacities to promote economic integration through improved connectivity, avoiding adverse impacts from development projects and creating wealth for future generations-not just one-off growth in incomes for some in the present generation.

With a high priority put on consultation and cooperation, the BRI can be seen as an important opportunity for diversifying and strengthening China's bilateral, regional and global cooperation in a multitude of institutional settings and arrangements that promote both economic and political security.

There are two main risks. The first relates to China's own policy in developing the BRI. Although the initiative is defined as inclusive and is designed to create mutual benefit, this goal will not be easy to achieve and will require a huge effort in international economic diplomacy and in building the capacities with which to engage. The porous policy institutions and environment of developing partners make this a particularly challenging task. The second, interdependent risk relates to the policies that other countries adopt towards China and the extent to which the principles of engagement take multilateral interests into account. Exclusively bilateral engagement will reduce partner options and limit the potential gains for growth and development (EAF 2017).

It is too soon to judge the impact of the BRI in these dimensions, but what is clear (and inevitable) in such an undertaking is that improvement on all these fronts is needed. The pattern of investment in energy projects, for example, has not been notably supportive of green growth, the environmental impact of some projects is subject to question and there are some 'white elephant' projects that waste resources for future generations. Resolving the policy inconsistencies and dilemmas that will help to avoid these less favourable outcomes is a major interest and priority. Success critically depends on the terms of engagement between China and its partners. 
The Belt and Road Forum in May 2017 was innovative and strategic in its invitation to national partners and international and regional organisations to join in getting the terms of engagement right (EAF 2017). Among the principles that are important to getting better outcomes on BRI objectives are: appeal to multilateral frameworks in financing and setting the standards of project development where possible; appeal to global and regional best practice in bilateral cooperation efforts; engagement with international consortia in project development and delivery; giving priority to sorting out objectives and goals with partners and socialising them carefully; and the patient alignment of interests and goals with those partners. This requires deep institutional infrastructure for cooperation and intensification of people-to-people exchanges, which will take some time.

The success or failure of the BRI-not only for China's economic diplomacy, but also for outcomes in the global economic regime-will depend on whether countries such as Australia, Japan and the European powers make the choice to join in multilateral engagement. The alternative is a world of transactional bilateral deals that threaten to corrode the openness of the global economic regime-a regime already at serious risk (EAF 2017).

\section{Trade and political clout}

The story of the globalisation of the Chinese economy is essentially about China signing on to the global rules-based trade regime through accession to the WTO and committing to large-scale domestic market reforms in compliance with those rules. This strategic choice delivered massive gains through trade to both China and its partners in the global economy. The realisation of huge gains from trade was not without large adjustment costs, in both China and its global trading partners, but the net gains from China's trade and growth, as noted above, have been enormous. They are reflected in the palpable lift in the welfare of the Chinese people, the impact on global incomes and the expanded consumption possibilities around the globe delivered by low-cost Chinese products.

There are two additional elements, however, that qualify this largely good news story and are important to how the next chapters of the Chinese trade story might unfold. Both have to do with the completeness of the rules-based system-first, in respect of how it constrains behaviour in the international markets it presently covers, and second, in respect of what issues in trade and commerce are still not covered within a multilateral framework. Any system of rules or norms is challenged intrinsically by the nature of its observance and by evolving circumstances that demand its extension in various ways. The trade regime is specially challenged in both these ways, partly but not only because of the level of pressure put on it by China's success. 
The first issue to consider is China's observance of the extant rules. In a number of ways, the trade rules that have applied to China are stricter than those that apply to other WTO members. The protocols of China's accession to the WTO bound it to remove all taxes and surcharges, in principle, from its export goods, including raw materials. Only in the most exceptional circumstances is China allowed under WTO rules to limit exports_-for example, through regulatory restrictions or export duties. This was the basis for action undertaken by the United States, Japan and the European Union against China for restricting exports of 'rare earth elements' in 2012 (Drysdale 2013). The protocols of China's accession to the WTO also subjected it to 'nonmarket economy' treatment under antidumping rules, and gave other members greater latitude in penalising Chinese imports on the grounds they are being dumped.

The rare earths case is perhaps the most frequently cited example of China using trade restrictions to exercise political clout inconsistently with the rules. Other examples include a freeze on Norwegian salmon imports after human rights activist Liu Xiaobo was awarded the Nobel Peace Prize and the economic measures imposed on South Korea following its announcement of installation of the THAAD missile defence system against North Korea.

In September 2010, a Chinese trawler and a Japanese coast guard vessel collided in the East China Sea. The Chinese captain was arrested and temporarily detained. Amid the tensions that followed, it was widely reported that China had stopped exporting certain rare earth metals (which are used in smartphone and other hightech production) to Japan (King and Armstrong 2013). The United States, Japan and the European Union requested consultation with China, formally opening three WTO dispute cases, in March 2012. While it is doubtful these restrictions were in fact used as an instrument of political coercion, as was commonly assumed (King and Armstrong 2013), when the panel found that China's export duties and quotas on the rare earths were in violation of its WTO commitments, China removed the measures, and full implementation of the panel's recommendations was recognised, despite an attempt at appeal from the United States, in May 2015 (WTO 2015).

China's observance of the trade rules in the rare earths case represents substantial vindication of the effectiveness of and protections provided by the international trade regime. ${ }^{10}$ As observed elsewhere, a dispute of this kind in the prewar period (when such a regime was absent) is likely to have resulted in serious political conflict (Armstrong 2009: 158-61).

10 Previous cases reveal that these rules on export trade have not applied universally. One striking example is the US embargo on soybean exports in 1973, at a time when Japan obtained about 92 per cent of its annual consumption of soybeans (a major staple) from the United States (see NYT 1973). The experience encouraged Australia to enter a treaty with Japan—its biggest food and raw materials market at the time—stipulating explicitly that it would not apply export restrictions to these commodities. In so doing, Australia sought to close the gap in assurances on export restrictions in the global system that the soybean case had opened (Drysdale 2013). 
In the South Korean THAAD case, despite Seoul's assurances that the THAAD system would 'not be used against a third party' such as China and despite then South Korean deputy prime minister Yoo Il-ho's prediction that, as a WTO member, 'China may find it difficult to take punitive economic measures on political issues', China took a number of economic measures aimed at putting pressure on Seoul (Lee 2017). ${ }^{11}$

The measures used against South Korea-like those used against Norway and the Philippines in other cases-were carefully crafted through the use of domestic regulations and controls so as not to offend against the letter of international trade law. While China's economic heft may have been used to exert political influence over partners, such action (however carefully crafted) is likely to diminish China's credibility in shaping and participating in the global economic institutions that have enabled its rise. In the South Korean case:

[I]t [was] in Beijing's interests for Seoul to reverse its THAAD decision; it [was] also in Beijing's interests for the rules and institutions of the international trading system, broadly, to hold together. (Lim and Ferguson 2017)

South Korea did not initiate a formal WTO dispute over the measures prompted by the installation of THAAD, but it did raise the matter with the WTO Council for Trade in Services to share the issue with 'multilateral parties'. A Chinese Commerce Ministry spokesperson responded that '[o]nly trade that complies with WTO rules can be considered fair trade' (Kong 2017).

These cases draw attention to areas in which the WTO-based system needs to be strengthened through its extension to cover related regulatory issues. With all its strengths, the system is imperfect and incomplete. The measures against South Korean products and firms were largely regulatory, often based on safety regulations or censorship, and hence difficult to formally dispute through the present WTO framework. They are issues for future negotiation.

A more important aspect of the question of using trade leverage for political clout around the rules relates to how observing the letter but not also the spirit of trade law may act to compromise trust in China's observance of the rules. Despite the

11 The measures targeted South Korea's entertainment, tourism and retail sectors. Between August 2016 and March 2017, several South Korean television programs were banned in China. Online South Korean video games were denied regulatory approval and concerts featuring popular South Korean performers were cancelled. Citing safety issues, regulators banned the sale of certain South Korean consumer products, including air purifiers and cosmetics. Applications by Korean airlines for new charter flights were denied, and the Chinese National Tourism Administration told agencies to reduce the sale of tour packages to South Korea. A South Korean 'hypermarket' conglomerate, Lotte, had transferred land (a golf course) to the government for THAAD's development. Within months, regulators had closed 87 of 112 Chinese Lotte stores—all for alleged safety violations-costing the conglomerate an estimated US\$2.2 billion. Beijing denied the THAAD issue and the economic measures were connected. Nonetheless, the measures contributed to heightened perceptions of Chinese political risk. See Meick and Salidjanova (2017: 7) and Lee (2017). 
large presence of state-owned entities and its one-party political system, China's attempts to uphold, and its observance of, international trade rules have generally been positive features of its participation in the system and have been favourably viewed internationally. In China, the WTO is arguably one of the most widely recognised and respected international organisations (Wang 2011). A narrative that plausibly connects developments in China's political system to lessened confidence in the reliability of its stake in the rules-based trading system would be damaging both to China and to the global system.

\section{The pressures and priorities today}

Two issues of significance in the conduct of international commerce today that are not yet systematically comprehended within multilateral trade rules or other multilateral institutions are foreign investment and cyber trade-international transactions and business made possible by the revolution in information technology. The foreign investment issue has been around for some time, and foreign investment has played a major role in China's economic modernisation. Its role has been larger in terms of its contribution to trade and income growth than in more advanced economies such as Japan or South Korea. The information technology revolution is a new phenomenon, the applications of which were in their infancy when China acceded to the WTO. A third area where the multilateral rules need to be extended is in services trade, where current General Agreement on Trade in Services (GATS) rules provide only partial coverage. Plurilateral initiatives such as the Trade in Services Agreement are under negotiation, and bilateral and regional agreements attempt to liberalise and protect the delivery of services behind the border, but they are an area where WTO coverage needs extension.

\section{Foreign investment}

East Asia's integration into the global economy has been closely linked to the role of foreign investment in the growth of efficient production networks and production chains across the region. Foreign investment has also been a major source of the international diffusion of technology and knowhow. China's early openness to foreign investment, initially through SEZs, saw it rapidly become the major centre of global manufacturing growth. In the early decades of China's opening, foreigninvested firms were the major source of Chinese trade and output growth. While Chinese foreign investment policy restricted foreign ownership shares in most activities that serviced the domestic market (commonly to 50 per cent or less in joint ventures with local enterprises), investment was welcomed as a source of international knowhow and technology and an agent of export growth. China was more open to foreign investment than most countries at a similar stage of economic 
development. It soon became the largest emerging market destination for foreign investment and, in 2016, the third-largest destination in the world (UNCTAD 2017: 12).

Meanwhile, the growth of China's industrial and investment capacity recommended opening up to investment abroad in search of resources, new international markets and technology as well as lower cost bases for production abroad as wage and other costs rose in China. In less than two decades, China has become the second-largest source of direct investment internationally, after the United States (UNCTAD 2017: xi).

Today, China is a major object of policy interest both as a destination for foreign investment and as a new investor in markets around the world. Obstacles to investment in China and their impact on the structure of competition between Chinese and US or European firms have become major issues in economic diplomacy. At the same time, anxieties about the rapid surge in and the special character of Chinese investment, with its preponderance of state-owned enterprises in many areas, have triggered more restrictive approaches to Chinese investment in a number of jurisdictions. As direct investment flows into and out of China have become more important, the lack of a global investment regime is emerging as a significant gap in the multilateral architecture.

In the absence of a multilateral investment regime, countries will have to suffice with a mix of both unilateral policies (mostly on the initiative of host countries) and bilateral arrangements under investment treaties and economic agreements that have varying provisions and protections. There is no bilateral investment treaty between China and the United States; a treaty has been under negotiation but so far there has been little progress.

This is currently an issue of huge importance. The Trump administration has launched a trade war against China ostensibly because of China's unfair treatment of American investors. Foreign investment ownership restrictions, it argues, force American and other foreign firms to surrender technologies to Chinese competitors. Trump's argument has some merit, although the measures China has used to build technological capabilities through investment policy have been part of the policy approach to promoting industrial development across all the 'catch-up' countries (including Japan). Negotiating this issue does not recommend or necessitate tearing down the rules-based global trading system to achieve a more satisfactory investment regime.

The interest in articulating a set of common multilateral principles for foreign investment-for both facilitating pre-establishment foreign investment (before it enters a country) and the national treatment of post-establishment foreign investment-is thus a high priority (EABER and CCIEE 2016: 229). The WTO 
investment facilitation initiative in 2017 offers a possible route forward multilaterally. But, realistically, the urgency of resolving these issues is likely to see bilateral settlements (between China and the United States) dominate outcomes if broader regional interests cannot productively be brought to bear on them.

\section{Cyber trade and next generation trade rules}

The huge growth of international transactions and business made possible by the revolution in information technology has taken place since the establishment of the WTO in 1995. When the Uruguay Round was negotiated (1986-94), the digital landscape and its effects on international commerce were in their infancy. More recent bilateral and regional agreements, such as the United States-Korea Free Trade Agreement (KORUS FTA) and the TPP, have begun to grapple with data issues, but the WTO has no explicit framework outside of norms such as transparency and nondiscrimination covering the big issues that the digital revolution presents for international policymakers.

The negotiation of the rules for cyber trade is now among the most important questions that confront the international trade regime. This is a new issue not yet systematically comprehended within the multilateral trade rules or other multilateral institutions. It requires the resolution of enormously complex technical and political issues among the major players such as China, the United States and Europe, but every country has a stake in this debate. Thus, it is far better that the resolution be multilaterally based (within the WTO or a related framework), but that is likely only if one or more of the key players, such as China, resolutely insists on a multilateral approach.

The regulation of international digital trade raises highly contested economic and political questions. There are strongly divergent policy approaches that reflect differences over the protection of established leaders in the business, alternative approaches to development, approaches to social and political control and the protection of security interests (Kennedy 2018). An open multilateral approach would provide the most credible framework through which countries can open formal disputes or defend their data regulation policies as they relate to international trade.

Existing trade agreements have tended to be vague on data regulation, although they represent valuable steps in developing international norms around the free flow of data. In 2011, the KORUS FTA became the first treaty with a binding commitment on data regulation, specifying that firms must 'endeavour to refrain from imposing or maintaining unnecessary barrier[s] to electronic information flows across borders', although this is subject to a binding exceptions provision (Meltzer 2013: 17; Office of the USTR 2010). Under the TPP and its replacement, the CPTPP, parties can bring disputes against data localisation measures, although there are sectoral exceptions for government and financial services (Selby 2017: 218). 
Another regional framework has been proposed by the European Commission, which suggests abolishing localisation laws for nonpersonal data as part of the EU Digital Single Market strategy (EC 2017).

Data localisation - the requirement that firms physically locate their servers within the country in which the data were generated-is an area of interest for trade and cybersecurity policymakers alike. Given the role of data flows in global production chains, as well as the growth of e-commerce and trade in data collection and analysis services, these laws create trade costs. Countries with less developed internet service industries, including China, have been more likely to introduce data localisation laws (Selby 2017: 232). The challenge will be to minimise the impact of these regulatory regimes on trade costs while remaining sensitive to different parties' capabilities and legitimate policy interests about data security.

China is the major focus of angst over internet filtering, including for the purposes of censorship, which has been acknowledged as a trade barrier by the United States since 2016 (Allen-Abrahamian et al. 2016). In recent years, debate ramped up over whether the United States should address the Chinese Government's internet filtering through the WTO. The Chinese Government's block list includes the US giants Google, Facebook, Twitter and YouTube-often to the benefit of domestic firms such as the Chinese search engine Baidu (Barfield 2016). Calls for a US WTO challenge against China often hark back to a 2005 dispute, which interpreted bans on foreign service providers as a 'zero quota' and hence in violation of the GATS. The likely counter from China would be to invoke a 'public order' exception and claim that reversing the ban would present a threat 'to one of the fundamental interests of society' (Wu 2006: 283-4; WTO 1995). Despite USTR reports identifying China's internet filtering as a trade barrier, a challenge over the issue has not yet been mounted at a high level, and the result is difficult to predict. China will be the key in transitioning towards a comprehensive multilateral framework for regulating cyber trade.

Larger countries or groups of countries will set protection standards, but these may inhibit data flows. The European Union introduced the General Data Protection Regulation in May 2018, which regulates how EU citizens' data are used, including by companies based outside the European Union that offer goods or services for European customers (EC 2018a, 2018b). How this will affect global data flows is not yet clear, but multilateral rulemaking would avoid potential complications.

What is clear is that global rules on internet filtering are not sufficiently developed to deal with the growing economic implications of data regulation, filtering and censorship; and that China's future participation in a regime that deals with these issues will clearly be contingent on it securing a stake in the institutions that underpin the regime. If left unresolved, this issue will further corrode confidence in the broader global trade regime. 


\section{Age of uncertainty}

Today the global trading system has entered an age of uncertainty: the multilateral rules-based trade regime is under assault and the liberal economic order that has underpinned trade growth and global prosperity is under threat from its chief architect, the United States. No response to this uncertainty is more important than China's.

Some people think the difficulties in international economic policy we face today all arose with the election of US President Donald Trump. That is an oversimplification of the matter. These difficulties are a consequence of significant shocks to economic and trade systems through the GFC as well as long-term structural changes in the global economy that have been shaking the system for some time.

These changes include the emergence of China and its accommodation in the global system. In North America itself, there are long-term structural problems that are the origin of the maldistribution of gains from international trade on which Trump built his political claim to the presidency. Trump and many of his followers blame China for these American woes, but most are structural problems of the United States' own making and their solution is in American hands alone. They require deep institutional and policy shifts and a different approach to social as well as international trade policy.

The notion that the United States has not reaped huge benefits and gains from international trade is false; US national income growth has been boosted massively by the gains from trade. But the distribution of the gains from trade is poorly served by domestic institutions (health, education, adjustment policies) and by policies that have seen real household incomes remain stagnant for decades. This will not change quickly, and certainly not in a presidential term; it will take a generation to fix.

Trump has declared trade war to right the wrongs he says the United States has been done by its trading partners, notably China. He blames them for US trade deficits. That, of course, is not the case. US trade deficits are a product of the United States spending more than it earns and covering the extra spending by importing capital in some form or other. There are issues to be negotiated with the rules of international trade and commerce, but they have little to do with righting international trade imbalances.

Trump's trade war is yet to be engaged, but if it is merely a negotiating tactic designed to shift the system forward, it is a costly and risky one. His talk of trade war has spooked financial markets. His fuelling of spending through tax cuts and delayed-action trade war will add to US imports through lifting US spending and front-loaded purchases from abroad. More importantly, his flouting of WTO trade 
rules and misidentification of trade restrictions as the cause of US trade deficits blow the credibility of US trade policy leadership, making it easier for other countries to tear down the system (EAF 2018).

China's importance in the global economy is second only to the United States. Its response to US action on trade will be crucial.

'The mood in Washington has shifted from engaging with China to hedging against it', Yang Yao (2018) argues. Yao identifies technological competition as the underlying issue that now confronts the China-United States relationship. The major justification for Trump's ill-advised declaration of trade war is Chinese 'theft' of US intellectual property and 'forced technology transfer'.

Punitive tariffs are just the warm up for a coming marathon in technological competition. In the years ahead, it is highly likely that the Trump administration will tighten up its control on Chinese companies' merger and acquisition activities in the United States. (Yao 2018)

Measures to transfer technology through investment policy have been part of policy to promote industrial development across all the 'catch-up' countries, such as Japan and South Korea, as well as China. Historically, of course, the United States played the same game (Morris 2012). State-led industrial policies have also been used to promote technological advancement. The additional dimension in China's case is the alleged state-mandated theft. All of that certainly needs to be negotiated and now needs to change. But none of this recommends tearing down the global trading system. The priority should rather be on investment facilitation, an investment agreement that deals with these issues and building a multilateral-based international digital economy regime.

As for China's response:

[I] $t$ is imperative for policymakers to recognise the change of attitude in Washington and form a new strategy to deal with the United States ... The right long-term response is to continue China's reform and opening policy, which has been critical to China's 40 years of high growth. (Yao 2018)

For the rest of the world, wait-and-see strategies are no longer viable. This is a time that requires strategic response, particularly from partners in Asia. China cannot frame the right response alone.

Asia has more at stake in the global system than any other part of the world; its economies depend on the open rules-based system not only for their economic prosperity, but also for their political security. The appeal to the rules-based system is a critical dimension of protecting economic security and of political security more broadly. Asian countries need to stand firm in the face of the threat to the global trade regime. The dynamic of Asian growth depends on remaining committed to 
the trade reform agenda and encouraging entrenchment and deepening-including by China, the South-East Asian economies and India-of the open rules-based international trading system (EAF 2018).

\section{References}

Allen-Abrahamian, B., Shirk, S., Parker, E. and de Jonquières, G. (2016), Should internet censorship be considered a trade issue?, ChinaFile, 12 April. Available from: www.chinafile.com/conversation/should-internet-censorshipbe-considered-trade-issue.

Armstrong, S. (2009), The Japan-China economic relationship: Distance, institutions and politics, $\mathrm{PhD}$ thesis, The Australian National University, Canberra.

Armstrong, S. (2012), The politics of Japan-China trade and the role of the world trade system, The World Economy 35(9): 1102-20. doi.org/10.1111/j.14679701.2012.01473.x.

Armstrong, S. (2017), A new deal in Asia, Foreign Affairs, 17 March. Available from: www.foreignaffairs.com/articles/asia/2017-03-17/new-deal-asia.

Armstrong, S. (2018), The new Trans-Pacific Partnership hunkers down against Trump, East Asia Forum, 4 March. Available from: www.eastasiaforum.org/2018/ 03/04/the-new-trans-pacific-partnership-hunkers-down-against-trump/.

Armstrong, S. and Pangestu, M. (2018), Asian economic integration: The state of play, in S. Armstrong and T. Westland (eds), Asian Economic Integration in an Era of Global Uncertainty, Canberra: ANU Press. doi.org/10.22459/ AEIEGU.01.2018.

Asia-Pacific Economic Cooperation (APEC) (2014), Annex A: The Beijing roadmap for APEC's contribution to the realization of the FTAAP, in 2014 Leaders' Declaration, Singapore: APEC Secretariat. Available from: www.apec.org/MeetingPapers/Leaders-Declarations/2014/2014_aelm/2014_aelm_annexa.aspx.

Barfield, C. (2016), A WTO challenge to China's internet censorship is long overdue, East Asia Forum, 26 May. Available from: www.eastasiaforum.org/2016/05/26/ a-wto-challenge-to-chinas-internet-censorship-is-long-overdue/.

Bloomberg News (2018), China's Xi pledges greater openness amid Trump trade dispute, Bloomberg News, 10 April. Available from: www.bloomberg.com/news/ articles/2018-04-09/xi-set-for-landmark-economic-speech-as-trump-tradefight-simmers. 
Brandt, L. and Rawski, T. G. (2008), China’s great economic transformation, in L. Brandt and T. G. Rawski (eds), China's Great Economic Transformation, Cambridge: Cambridge University Press.

Branstetter, L. and Lardy, N. (2008), China's embrace of globalization, in L. Brandt and T. G. Rawski (eds), China's Great Economic Transformation, Cambridge: Cambridge University Press. doi.org/10.1017/CBO9780511754234.017.

Chen, C. (2011), The development of China's FDI laws and policies after WTO accession, in J. Golley and L. Song (eds), Rising China: Global challenges and opportunities, Canberra: ANU E Press.

Drysdale, P. (2000), Open regionalism, APEC and China's international trade strategies, in P. Drysdale, Y. Zhang and L. Song (eds), APEC and Liberalisation of the Chinese Economy, Canberra: Asia Pacific Press.

Drysdale, P. (2013), China and the norms of trade, East Asia Forum, 19 August. Available from: www.eastasiaforum.org/2013/08/19/china-and-the-norms-oftrade/.

Drysdale, P. (2016), The regional trade deal with China and India that's twice the size of TPP, The Australian Financial Review, 26 April. Available from: www. afr.com/opinion/the-regional-trade-deal-with-china-and-india-thats-twice-thesize-of-tpp-20160426-goeyzj.

Drysdale, P. (2017), ASEAN: The experiment in open regionalism that succeeded, in R. Sta. Maria, S. Urata and P. S. Intal, jr (eds), The ASEAN Economic Community Into 2025 and Beyond, Jakarta: Economic Research Institute for ASEAN and East Asia. Available from: eria.org/5.1.ASEAN_50_Vol_5_Drysdale.pdf.

Drysdale, P. and Armstrong, S. (2015), Foreign economic policy strategies and economic performance, in Y. Funabashi and B. Kushner (eds), Examining Japan's Lost Decades, London: Routledge.

Drysdale, P. and Terada, T. (eds) (2007), Asia-Pacific Economic Cooperation: Critical perspectives on the world economy, London: Routledge.

East Asia Forum (EAF) (2017), How to respond to China's Belt and Road Initiative, East Asia Forum, 15 May. Available from: www.eastasiaforum.org/2017/05/15/ how-to-respond-to-chinas-belt-and-road-initiative/.

East Asia Forum (EAF) (2018), China-US trade face-off, East Asia Forum, 16 April. Available from: www.eastasiaforum.org/2018/04/16/china-us-trade-face-off/.

East Asian Bureau of Economic Research (EABER) and China Center for International Economic Exchanges (CCIEE) (2016), Partnership for Change: Australia-China joint economic report, Canberra: ANU Press. 
European Commission (EC) (2017), Free flow of non-personal data, Brussels: EC. Available from: ec.europa.eu/digital-single-market/en/free-flow-non-personaldata.

European Commission (EC) (2018a), What does the General Data Protection Regulation (GDPR) govern?, Brussels: EC. Available from: ec.europa.eu/info/law/ law-topic/data-protection/reform/what-does-general-data-protection-regulation -gdpr-govern_en.

European Commission (EC) (2018b), Who does the data protection law apply to?, Brussels: EC. Available from: ec.europa.eu/info/law/law-topic/data-protection/ reform/rules-business-and-organisations/application-regulation/who-does-dataprotection-law-apply_en.

Garnaut, R. (2012), Indonesia in the new world balance, in A. Reid (ed.), Indonesia Rising: The repositioning of Asia's third giant, Singapore: Institute of Southeast Asian Studies. doi.org/10.1355/9789814380416-008.

Garnaut, R. and Huang, Y. (2000), China and the future of the international trading system, in P. Drysdale and L. Song (eds), China's Entry to the WTO: Strategic issues and quantitative assessments, London: Routledge. doi.org/10.4324/ 9780203398227_chapter_2.

Gewirtz, J. (2017), Unlikely Partners: Chinese reformers, Western economists, and the making of global China, Cambridge, MA: Harvard University Press. doi.org/ $10.4159 / 9780674973459$.

Golley, J. and Song, L. (2011), China's rise in a changing world, in J. Golley and L. Song (eds), Rising China: Global challenges and opportunities, Canberra: ANU E Press.

Halverson, K. (2004), China's WTO accession: Economic, legal, and political implications, Boston College International and Comparative Law Review 27(2): 319-70.

Kennedy, A. (2018), How Trump is losing the high-tech fight with China, East Asia Forum, 27 May. Available from: www.eastasiaforum.org/2018/05/27/howtrump-is-losing-the-high-tech-fight-with-china/.

King, A. and Armstrong, S. (2013), Did China really ban rare earth metals exports to Japan?, East Asia Forum, 18 August. Available from: www.eastasiaforum. org/2013/08/18/did-china-really-ban-rare-earth-metals-exports-to-japan/.

Kong, K. (2017), South Korea lobbies China at WTO over missile shield trade spat, Bloomberg, 20 March. Available from: www.bloomberg.com/news/articles/ 2017-03-20/south-korea-lobbies-china-at-wto-over-missile-shield-trade-spat. 
Lee, J. (2017), Back to normal? The end of the THAAD dispute between China and South Korea, China Brief 17(15). Available from: jamestown.org/program/ back-normal-end-thaad-dispute-china-south-korea/.

Lemoine, F., Poncet, S. and Unal, D. (2015), Spatial rebalancing and industrial convergence in China, China Economic Review 34: 39-63. doi.org/10.1016/j. chieco.2015.03.007.

Liang, W. (2002), China's WTO negotiation process and its implications, Journal of Contemporary China 11(33): 683-719. doi.org/10.1080/106705602200000 8878 .

Lim, D. J. and Ferguson, V. (2017), Costs of Chinese boycotts cut both ways, East Asia Forum, 5 April. Available from: www.eastasiaforum.org/2017/04/05/ costs-of-chinese-boycotts-cut-both-ways/.

Meick, E. and Salidjanova, N. (2017), China's response to US-South Korean Missile Defense System deployment and its implications, Report for the US-China Economic and Security Review Commission, Washington, DC: US Congress.

Meltzer, J. P. (2013), The internet, cross-border data flows and international trade, Issues in Technology Innovation Report, 25 February, Washington, DC: Center for Technology Innovation at The Brookings Institution. Available from: www. brookings.edu/wp-content/uploads/2016/06/internet-data-and-trade-meltzer.pdf.

Meltzer, J. P. (2017), Global digital trade 1: Market opportunities and key foreign trade restrictions, Testimony, 12 April, Washington, DC: The Brookings Institution. Available from: www.brookings.edu/testimonies/global-digital-trade1-market-opportunities-and-key-foreign-trade-restrictions/.

Morris, C. (2012), We were pirates, too, Foreign Policy, 6 December. Available from: www.foreignpolicy.com/2012/12/06/we-were-pirates-too/.

National Bureau of Statistics of China (NBS) (various years), China Statistical Yearbook. Available from: www.stats.gov.cn/english/statisticaldata/annualdata/.

The New York Times (NYT) (1973), Japanese upset by US soybean curbs, The New York Times, 7 July. Available from: www.nytimes.com/1973/07/07/archives/ japanese-upset-by-us-soybean-curbs-u-s-ban-on-soybean-exports-is.html.

Office of the Press Secretary (1999), Joint press conference with President Clinton and Premier Zhu Rongji of the People's Republic of China, 8 April, Presidential Hall, Washington, DC. Available from: clintonwhitehouse4. archives.gov/textonly/WH/New/html/19990408-1109.html. 
Office of the United States Trade Representative (USTR) (2010), Free Trade Agreement between the United States of America and the Republic of Korea, Washington, DC: Office of the USTR. Available from: ustr.gov/trade-agreements/free-tradeagreements/korus-fta/final-text.

Office of the United States Trade Representative (USTR) (2018), 2017 Report to Congress on China's WTO Compliance, Washington, DC: Office of the USTR.

Pregelj, V. N. (2005), The Jackson-Vanik amendment: A survey, CRS Report for Congress, Washington, DC: Congressional Research Service, The Library of Congress.

Selby, J. (2017), Data localization laws: Trade barriers or legitimate responses to cybersecurity risks, or both?, International Journal of Law and Information Technology 25: 213-32. doi.org/10.1093/ijlit/eax010Selby.

Song, L. (2013), China's rapid growth and development: A historical and international context, in Y. Huang and M. Yu (eds), China's New Role in the World Economy, London: Routledge.

United Nations Conference on Trade and Development (UNCTAD) (2017), World Investment Report 2017: Investment and the digital economy, Geneva: UNCTAD. Available from: unctad.org/en/PublicationsLibrary/wir2017_en.pdf.

Wang, Y. (2011), China's development since WTO accession, East Asia Forum, 6 October. Available from: www.eastasiaforum.org/2011/10/06/chinasdevelopment-since-wto-accension/.

World Bank (2009), China_From poor areas to poor people: China's evolving poverty reduction agenda-an assessment of poverty and inequality, Poverty Assessment No. 47349, Washington, DC: The World Bank. Available from: documents. worldbank.org/curated/en/816851468219918783/China-From-poor-areasto-poor-people-Chinas-evolving-poverty-reduction-agenda-an-assessment-ofpoverty-and-inequality.

World Bank (2018), World Bank Open Data. Available from: data.worldbank.org/.

World Integrated Trade Solution (WITS) (2018), China trade statistics. Available from: wits.worldbank.org/CountryProfile/en/CHN.

World Trade Organization (WTO) (1995), General Agreement on Trade in Services: Article XIV Note 5, in Uruguay Round Agreement, Geneva: WTO. Available from: www.wto.org/english/docs_e/legal_e/26-gats_01_e.htm\#fnt-5. 
World Trade Organization (WTO) (2015), China: Measures related to the exportation of rare earths, tungsten and molybdenum, Dispute Settlement No. 431, Geneva: WTO. Available from: www.wto.org/english/tratop_e/dispu_e/cases_e/ds431 _e.htm.

World Trade Organization Secretariat (WTO Secretariat) (2018), Time series on international trade. Available from: stat.wto.org/StatisticalProgram/WSDBStat ProgramHome.aspx? Language=E.

Wu, T. (2006), The world trade law of censorship and internet filtering, Chicago Journal of International Law 7(1): 263-87.

Xi, J. (2017), Jointly shoulder responsibility of our times, promote global growth, Keynote speech, 2017 World Economic Forum, 17 January, Davos, Switzerland. Available from: www.china.org.cn/node_7247529/content_40569136.htm.

Yang, Y. and Huang, Y. (2000), How important is APEC to China?, in P. Drysdale, Y. Zhang and L. Song (eds), APEC and Liberalisation of the Chinese Economy, Canberra: Asia Pacific Press.

Yao, Y. (2013), Double transition and China's export-led growth, in Y. Huang and M. Yu (eds), China's New Role in the World Economy, London: Routledge.

Yao, Y. (2018), Another messy falling out in China-US relations, East Asia Forum, 15 April. Available from: www.eastasiaforum.org/2018/04/15/another-messyfalling-out-in-china-us-relations/.

Zhang, Y. (2000), Liberalisation of the Chinese economy: APEC, WTO and tariff reductions, in P. Drysdale, Y. Zhang and L. Song (eds), APEC and Liberalisation of the Chinese Economy, Canberra: Asia Pacific Press. 
This text is taken from China's 40 Years of Reform and Development: 1978-2018, edited by Ross Garnaut, Ligang Song and Cai Fang, published 2018 by ANU Press, The Australian National University, Canberra, Australia.

doi.org/10.22459/CYRD.07.2018.27 